I.В. СМЧЕНКО

Львівський торговельно-економічний університет

\title{
МИТНІ ОЗНАКИ ІДЕНТИФІКАЦІї СИНТЕТИЧНИХ МИЙНИХ ЗАСОБІВ
}

\author{
И.В. ЕМЧЕНКО \\ Львовский торгово-экономический университет
}

\section{ТАМОЖЕННЫЕ ПРИЗНАКИ ИДЕНТИФИКАЦИИ СИНТЕТИЧЕСКИХ МОЮЩИХ СРЕДСТВ}

I.YEMCHENKO

Lviv university of Trade and Economics

\section{CUSTOMS IDENTIFICATION SIGNS OF SYNTHETIC DETERGENTS}

\section{https://doi.org/10.36910/6775-2310-5283-2018-11-22}

Мета. Визначення ознак ідентифікаиії синтетичних мийних засобів згідно із вимогами технічних регламентів під час здійснення митних процедур. Важливим $\epsilon$ встановлення основних ознак ідентифікації синтетичних мийних засобів в митних иілях.

Методика. При дослідженнях використовували методи на основі системного аналізу та органолептичні методи візуального контролю. Для підведення підсумків роботи використовували методи аналізу та синтезу інформаиії, абстрагування та групування.

Результати. Проаналізовані представлені дані щзодо найбільших у світі країнекспортерів та країн-імпортерів синтетичних мийних засобів у 2017 році. Окреслені визначення основних вимог щодо якості та екологічної безпечності синтетичних мийних засобів у світлі гармонізачії вимог технічних регламентів. Визначені ознаки товарознавчої та митної ідентифікаџії. Адже ідентифікація в митних ичілях є складовою необхідних митних процедур, а саме митного оформлення при здійсненні зовнішньоторговельних операцій.

Наукова новизна. Проведено аналіз ознак митної ідентифікації, як критерія митної класифікачіï під час декларування синтетичних мийних засобів, щзо $\epsilon$ об’єктом зовнішньоекономічних операцій. Встановлено оптимальний перелік класифікаційних ознак синтетичних мийних засобів, який дозволяє достатньо ідентифікувати в митних иілях під час здійснення митних процедур.

Практична значимість. Визначені критерії ідентифікації синтетичних мийних засобів дозволяють чітко класифікувати об'єкт митного контролю з метою застосування механізмів митного тарифного та нетарифного регулювання.

Ключові слова: ідентифікація, синтетичні мийні засоби, класифікація, асортимент, митний контроль, митне оформлення, технічний регламент.

Постановка проблеми у загальному вигляді та її зв'язок із важливими науковими чи практичними завданнями. Оскільки до складу синтетичних мийних засобів (СМ3) входять небезпечні речовини, то до них $-(191$ 
ставляться високі вимоги щодо безпечності як для здоров’я споживачів та i для стану навколишнього середовища. Тому актуальним $\epsilon$ розширення наявного асортименту мийних засобів, особливо на основі натуральних поверхнево-активних речовин. У зв’язку з цим, виникає завдання визначення відповідності вимог щодо якості та екологічної безпечності СМЗ у плані гармонізації із вимогами технічних регламентів та визначення ознак товарознавчої та митної ідентифікації. Адже ідентифікація в митних цілях $є$ складовою необхідних митних процедур, а саме митного оформлення при здійсненні зовнішньоторговельних операцій. Виникає необхідність у встановленні показників, що впливають на ознаки митної класифікації та застосування механізмів митно-тарифного та нетарифного регулювання піж час митного оформлення СМЗ, що є об’єктом зовнішньоторговельних операцій.

Незважаючи на значну кількість досліджуваних проблем та присвяченим їм публікацій, теоретичні та практичні аспекти декларування зовнішньоекономічних операцій, об’єктом яких є синтетичні мийні засоби та їх ідентифікація в митних цілях $\epsilon$ актуальними та потребують подальшого дослідження.

Аналіз останніх досліджень, у яких започатковано вирішення проблеми. Незважаючи на значну кількість досліджуваних проблем та присвяченим їм публікацій, теоретичні та практичні аспекти декларування зовнішньоекономічних операцій, об’єктом яких є СМЗ та їх ідентифікація в митних цілях є актуальними та потребують подальшого дослідження. Такими вченими-дослідниками, як Передрій О.І., Омельченко Н.В., Барна М.Ю., проводилися дослідження формування ринку СМЗ в Україні та розглядалися питання безпечності мийних засобів в аспекті вимог нормативного законодавства ЄС та пропозицій застосування альтернативних безфосфатних ПАР з метою зменшення екологічного шкідливого впливу.

Цілі статті. Важливим $є$ проведення ідентифікації імпортованих в Україну синтетичних мийних засобів під час процедур митного оформлення, як об’єктів переміщення через митний кордон України та встановити основні ознаки ідентифікації СМЗ в митних цілях.

Об'скт дослідження. Об'єктом дослідження були порошкоподібні синтетичні мийні засоби імпортного виробництва (Болгарія), а також товаросупровідні документи, за якими здійснювалась ідентифікація основних ознак, визначальних для класифікації в митних цілях. 
Методи дослідження. У статті використовувались методи на основі системного аналізу та органолептичні методи візуального контролю. Для підведення підсумків роботи використовували методи аналізу та синтезу інформації, абстрагування та групування.

Виклад основного матеріалу дослідження з повним обгрунтуванням отриманих наукових результатів. Сучасні тенденції розвитку ринку синтетичних мийних засобів в Україні дають можливість спрогнозувати подальше зростання попиту. Пропозиція СМЗ забезпечується за рахунок експорту. Експорт синтетичних мийних засобів оцінювався в розрізі країн як у кількісному виразі (у кг), та i у вартісному (у тис. дол. США). Нами представлена інформація щодо найбільших у світі країн-експортерів СМЗ у 2017 році і які розташовані за порядком зменшення експортних постачань у кількісному виразі (табл. 1) [1, 2, 7].

Таблиця 1

Найбільші у світі країни - експортери СМЗ у 2017 році

\begin{tabular}{|l|c|c|}
\hline \multirow{2}{*}{ Найменування } & \multicolumn{2}{|c|}{ Експорт } \\
\cline { 2 - 3 } & Кількість, кг & Вартість, тис. дол. США \\
\hline Всього & $16.708429,5$ & 14324,3 \\
\hline Країни СНД & $6.590418,2$ & 6802,9 \\
\hline Країни Свросоюзу & $8.240751,9$ & 5618,7 \\
\hline Франція & $3.135192,0$ & 2084,0 \\
\hline Велика Британія & $2.868633,6$ & 1932,9 \\
\hline Грузія & 773554,3 & 805,5 \\
\hline Туреччина & 874214,2 & 589,1 \\
\hline Іспанія & 578499,0 & 395,1 \\
\hline Румунія & 359128,1 & 255,9 \\
\hline Італія & 291324,0 & 194,2 \\
\hline Греція & 275480,0 & 184,0 \\
\hline Нідерланди & 235227,9 & 63,4 \\
\hline Польща & 223079,2 & 243,2 \\
\hline Литва & 96456,8 & 115,9 \\
\hline Австрія & 18803,0 & 15,4 \\
\hline Болгарія & 16000,8 & 23,4 \\
\hline
\end{tabular}

За даними митної статистики, найбільшою країною-експортером СМЗ ЄС є Франція (2084,0 тис. дол. США), на другому місці - Велика Британія (1932,9 тис. дол. США), третє місце посідає Грузія (805,5 тис. дол. США). За останні роки спостерігається збільшення обсягів імпортних операцій щодо СМЗ. Якщо у 2013 р. у розрізі товарних позицій УКТЗЕД частка імпорту СМ3 становила 0,36 \%, то вже у 2016 р. - 0,44 \% [1]. Найбільші країниімпортери СМЗ країн СС наведені на рис. 1. 
Товарознавчий вісник. - 2018. - Випуск 11.

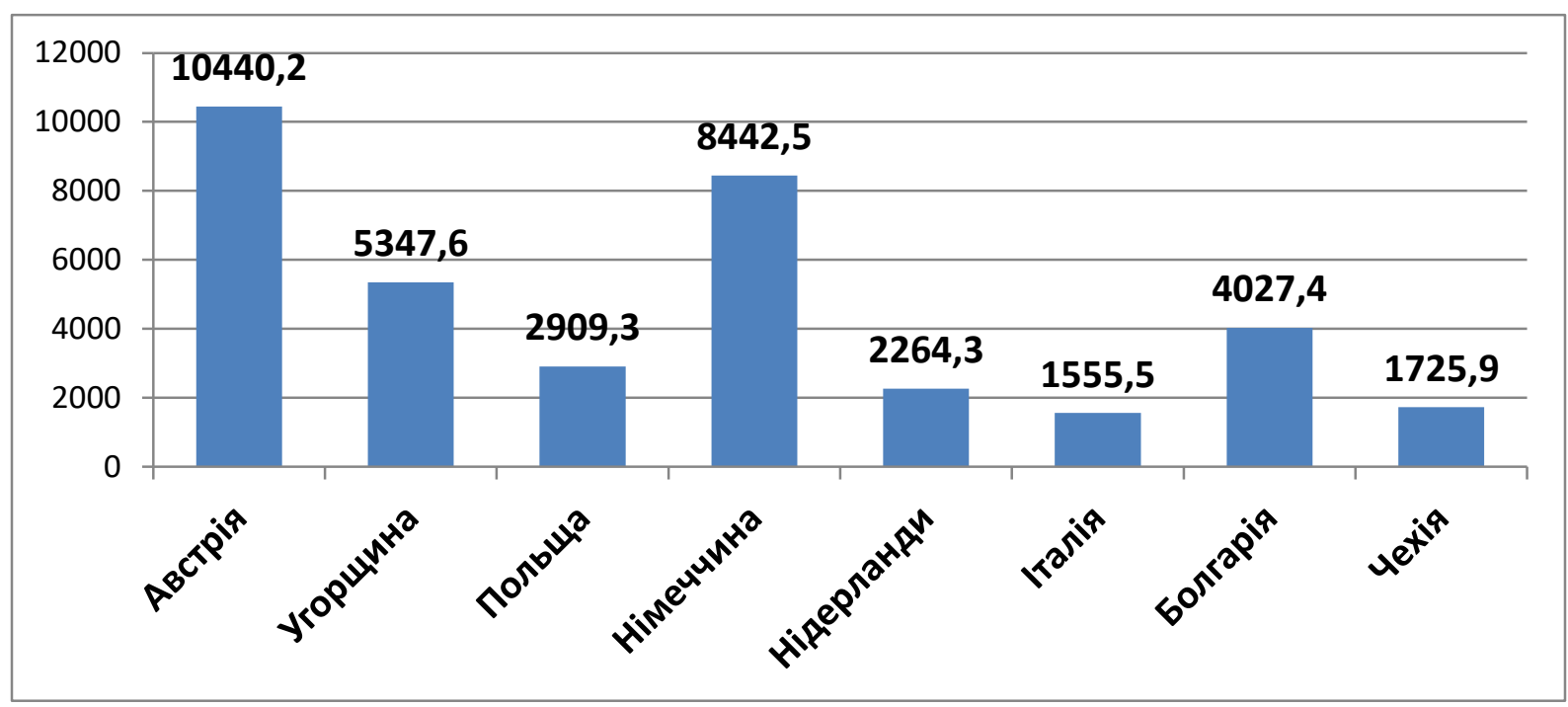

Рис. 1. Найбільші країни-імпортери СМЗ в Свропі за обсягом поставок за 2017 рік у вартісному виразі (тис. дол. США)

Якщо у 2013 р. у розрізі товарних позицій УКТЗЕД частка імпорту СМЗ в Україну становила 0,36 \%, то вже у 2016 р. - 0,44 \%. Експорт відповідно становив $0,12 \%$ та $0,05 \%$ (табл. 2) [3, 4].

Таблиця 2

Сумарний обсяг імпорту та експорту товарної позиції 3402 «оверхневоактивні речовини, засоби для прання, миття та чищення» у розрізі товарних позицій УКТЗЕД

\begin{tabular}{|c|c|c|c|c|c|c|}
\hline \multirow{2}{*}{ Роки } & \multicolumn{3}{|c|}{ Імпорт } & \multicolumn{3}{c|}{ Експорт } \\
\cline { 2 - 7 } & $\begin{array}{c}\text { Вартість, тис. дол. } \\
\text { США }\end{array}$ & $\begin{array}{c}\text { Частка, } \\
\%\end{array}$ & $\begin{array}{c}\text { Вага } \\
\text { нетто, т }\end{array}$ & $\begin{array}{c}\text { Вартість, } \\
\text { тис.дол.США }\end{array}$ & $\begin{array}{c}\text { Частка, } \\
\%\end{array}$ & $\begin{array}{c}\text { Вага нетто, } \\
\text { т }\end{array}$ \\
\hline 2012 & 264202 & 0,32 & 152873 & 60938 & 0,09 & 41773 \\
\hline 2013 & 275681 & 0,36 & 168085 & 76728 & 0,12 & 55236 \\
\hline 2014 & 229578 & 0,44 & 148135 & 73358 & 0,14 & 54690 \\
\hline 2015 & 155761 & 0,43 & 122683 & 33424 & 0,09 & 330 \\
\hline 2016 & 171939 & 0,44 & 143041 & 18356 & 0,05 & 19321 \\
\hline
\end{tabular}

Проте обсяги виробництва синтетичних мийних засобів та засобів для чищення в Україні за 2013-2016 роки знижувалися, що обумовлено об’єктивними чинниками (табл. 3). Тому уряд повинен втручатись у ринок, вимагаючи, щоб товари побутової хімії відповідали мінімальним стандартам технічним регламентам, які були зроблені обов'язковими за допомогою певного законодавчого механізму [5, 6]. 
Обсяги виробництва синтетичних мийних засобів та засобів для чищення в Україні за 2013-2016 роки

\begin{tabular}{|c|c|c|c|c|}
\hline Роки & 2013 & 2014 & 2015 & 2016 \\
\hline Обсяг, тис. тон & 269 & 262 & 197 & 190 \\
\hline
\end{tabular}

Серед комплексу чинників навколишнього середовища, які підлягають підвищеній регламентації, значну увагу приділяють хімічним препаратам побутового призначення у зв'язку 3 їх масовим виробництвом, різноманітністю компонентів i рецептур, a також 3 потенційним безпосереднім впливом на організм споживачів. Синтетичні мийні засоби значно змінюють «фон» сучасної оселі. Це спричинило розроблення нормативних документів, які регламентують вплив небезпечних речовин [5, 6]. Перехід українських товаровиробників на світові стандарти якості продукції і виробництва. У цьому аспекті дуже актуальним є заборона на рівні держави пральних порошків із вмістом фосфатів. Але всі нормативні документи узгоджені із змістом та вимогами Технічного регламенту на синтетичні мийні засоби.

Законодавство України дозволяє імпортувати і застосовувати пральні порошки, що містять у собі до $35 \%$ фосфатів [7, 8].

Як зазначено у Технічному регламенті уведення в обіг мийні засоби та поверхнево-активні речовини можуть вводитися в обіг за умови, якщо вони не загрожують безпеці навколишнього природного середовища та відповідають вимогам щодо рівня біологічного розкладу поверхнево-активних речовин; маркування мийних засобів; інформації, яка надається на запит визначених законодавством органів виконавчої влади; обмеження щодо вмісту фосфатів та інших сполук фосфору в мийних засобах $[8,10]$.

Важливість ідентифікації даних, зазначених на маркуванні синтетичних мийних засобів вимогам Технологічного регламента очевидно. Адже за даними проведеної ідентифікації надаеться документ - Декларація відповідності. Технічним регламентом визначені вимоги до маркування синтетичних мийних засобів (табл. 4).

Оцінювання відповідності вимогам Регламенту здійснюється із застосуванням процедур оцінки відповідності згідно з Технічним регламентом модулів оцінки відповідності, які використовується для розроблення процедур оцінки відповідності затвердженого Постановою Кабінету Міністрів України від 13 січня 2016 р. № 95 [10].

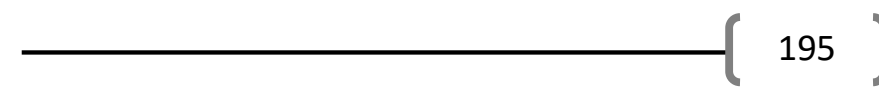


Таблиця 4

Дані, зазначені у маркуванні на пакованні СМЗ

\begin{tabular}{|l|l|}
\hline $\begin{array}{l}\text { - найменування та інформації про призначення } \\
\text { мийного засобу; }\end{array}$ & $\begin{array}{l}\text { - інструкції із застосування, заходів } \\
\text { безпеки та спеціальних застережень } \\
\text { згідно із законодавством }\end{array}$ \\
\hline $\begin{array}{l}\text {-торговельної марки (за наявності) або } \\
\text { торговельного знака; }\end{array}$ & -маси нетто чи об'єму; \\
\hline $\begin{array}{l}\text {-найменування, місцезнаходження та номера } \\
\text { телефону виробника мийного засобу або його } \\
\text { уповноваженого представника; }\end{array}$ & -дати виготовлення; \\
\hline $\begin{array}{l}\text {-інформації про склад мийного засобу згідно з } \\
\text { додаткомТехнічного регламенту на мийні засоби; }\end{array}$ & -строку придатності; \\
\hline $\begin{array}{l}\text { - адреси, зокрема електронної пошти (за } \\
\text { наявності), та номера телефону, за якими можна } \\
\text { одержати технічний опис інгредієнтів; }\end{array}$ & -умов зберігання (в разі потреби). \\
\hline
\end{tabular}

Оцінювання відповідності мийних засобів передбачає одну 3 нижче наведених процедур та/обо їх поєднання: облік декларації про відповідність вимогам Регламенту; сертифікація продукції; оцінка системи управління якістю.

Ідентифікація здійснюється:

- щодо назви продукції, країни-виробника (для продукції, що імпортується) - перевіркою назви в заявці на оцінку відповідності продукції, в контракті (договорі) на поставку, в товаро-супровідних документах, в паспортах якості (при наявності) та маркувальних даних;

- щодо органолептичних показників - перевіркою зовнішнього стану (рідина, порошок, гель, паста, крем тощо кольору та запаху;

- щодо функціонального призначення - згідно із технічною документацією;

- щодо маркування - перевіркою інформаційних даних, нанесених на зразок продукції чи на маркувальну етикетку в доступній для сприйняття формі, основних технічних чи споживчих характеристик (властивостей), зокрема інформаційних;

- операційних, застережливих знаків, гарантійних зобов'язань, зберігання (придатності) продукції.

Маркування зразків продукції на іноземній мові повинне бути надане в перекладі, засвідченому належним чином:

- щодо пакування - перевіркою транспортного пакування та фасування в споживчу тару; 
- щодо товаросупровідної документації (для продукції, що імпортується) - перевіркою приналежності продукції, заявленої на оцінку відповідності, як такої, що ввезена на митну територію України;

- одо обсягу партії продукції (при оцінці відповідності партії продукції) - перевіркою заявленої кількості продукції в партії стосовно заявки на оцінку відповідності, документа про кількість продукції (для вітчизняної продукції) та товаро-супровідних документів (для імпортованої продукції);

- щодо нормативного документу на продукцію - за підсумковими результатами перевірки вищевказаних показників (характеристик) на відповідність чинним НД в Україні або співвіднесеним за показниками (характеристиками) до НД на аналогічну продукцію.

Важливою складовою експертних досліджень є ідентифікаційні ознаки, які закладені в УКТЗЕД [4]. Важливим є класифікація об'єктів переміщення через митний кордон за УКТЗЕД та ДКПП.

Ідентифікують синтетичні мийні засоби за кодами у Державному класифікаторі продукції і послуг та за Українською класифікацією товарів зовнішньоекономічної діяльності (табл. 5).

Таблиця 5

\section{Ідентифікація синтетичних мийних засобів із кодами у класифікаторах}

\begin{tabular}{|c|l|l|}
\hline Код ДКПП & \multicolumn{1}{|c|}{ Код УКТЗЕД } & \multicolumn{1}{|c|}{ Назва продукції } \\
\hline 20.41 .32 & 3402209000 & $\begin{array}{l}\text { мийні засоби та засоби для чищення, } \\
\text { розфасовані для роздрібної торгівлі }\end{array}$ \\
\hline
\end{tabular}

Високий рівень попиту на синтетичні мийні засоби роблять їх предметом фальсифікації i контрафакції, для запобігання якої необхідно вживання специфічних засобів ідентифікації. Оскільки одним 3 головних результатів євроінтеграції в галузі митних відносин для України має бути гармонізація митних формальностей, зокрема ідентифікації в митних цілях.

Одним із завдань органів доходів і зборів Державної фіскальної служби України є митна ідентифікація як складової митних процедур. 3 огляду на те, що товари, що ввозяться в Україну згідно із міжурядовою угодою України $з$ державами САВТ оподатковуються ввізним митом за зниженими ставками.

Згідно із Наказом Мінфіну № 998 від 17.09.2012 р. при декларуванні СМЗ подається додаткова інформація необхідна для ідентифікації, що вноситься до електронного інвойсу, який додається до митної декларації, заповненої на бланку САД [11]. Ідентифікація СМЗ здійснюється, перш за все, згідно із ознаками у класифікаторах. Ознаками митної ідентифікації для

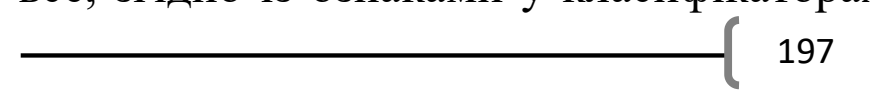


СМЗ $є$ тип фасування, тип ПАР, вміст допоміжних компонентів, вміст мийних речовин, \% до маси, призначення. Ідентифікують СМЗ згідно із структурою коду за УКТЗЕД.

У МД подаються ознаки класифікації СМЗ достатні для ідентифікації 3 метою застосування митних заходів регулювання.

Ідентифікація СМЗ за даними у 31 графі митної декларації МД-2 включає опис товару, маркування та кількість, розпізнавальні особливості (табл. 6).

Таблиця 6

Ідентифікація СМЗ за даними у 31 графі митної декларації МД-2

\begin{tabular}{|l|c|c|}
\hline \multicolumn{1}{|c|}{ Вантажні місця та опис товарів } & $\begin{array}{c}\text { Маркування } \\
\text { та кількість }\end{array}$ & $\begin{array}{c}\text { Розпізнавальні } \\
\text { особливості }\end{array}$ \\
\hline $\begin{array}{l}\text { Мийні засоби порошкоподібні, розфасовані для роздрібної } \\
\text { торгівлі - пральний порошок, що містить аніонні } \\
\text { поверхнево-активні речовини алкілсульфати), карбонати, } \\
\text { сульфати, фосфати, хлориди та речовини з } \\
\begin{array}{l}\text { люмінісцентними властивостями, додатково містять } \\
\text { ензими, оптичні відбілювачі парфумерну композицію } \\
\text { Siavex } \\
\text { Parfum Color } \\
\text { Brightnes } \\
\text { handwash }\end{array}\end{array}$ & 369 шт. \\
\hline
\end{tabular}

Висновки та перспективи подальших досліджень. Проаналізовані товаросупровідні документи, які подаються до митного оформлення, зроблена ідентифікація документів, які зазначені у 44 графі МД, а також класифікаційні показники. Визначені ознаки товарознавчої та митної ідентифікації, адже ідентифікація в митних цілях $\epsilon$ складовою необхідних митних процедур. Показані класифікаційні ознаки, що дозволяють ідентифікувати об'єкт митного оформлення під час переміщення через митний кордон. У подальшому важливим $\epsilon$ чітко визначити мінімальний перелік ідентифікаційних ознак для встановлення потенційно небезпечної тарифної позиції.

\section{Література}

1. Митна статистика [Електронний ресурс]. - Режим доступу : http://sfs.gov.ua/ms/f11

2. Статистичний бюлетень «Виробництво промислової продукції за видами в Україні» за 2017 р. / Державна служба статистики [Електронний ресурс]. - Режим доступу : http://www.ukrstat.gov.ua.

3. Український класифікатор товарів зовнішньоекономічної діяльності. [Електронний ресурс]. - Режим доступу : http://www.liga.com.ua. 
4. Проект закону Міністерства економічного розвитку і торгівлі України «Про особливості державного регулювання синтетичних мийних засобів та товарів побутової [Електронний ресурс].

Режим доступу http://w1.c1.rada.gov.ua/pls/zweb2/webproc4_1?pf3511=60104

5. Рудавська Г.Б., Санітарно-гігієнічна експертиза товарів: Підручник. - К.: Київ.нац.торг.-екон.ун-т, 2003. - 409 с.

6. Технічний регламент мийних засобів, затверджений постановою Кабінету Міністрів України 20.08.2008, № 717 (у редакції постанови Кабінету Міністрів України від 12червня 2013 р. № 408) // Законодавство України.-http://zakon2.rada.gov.ua/ laws/show/4082013-\%D0\%BF.

7. Проект Закону України «Про засади здійснення державного регулювання синтетичних миючих засобів та товарів побутової хімії» [Електронний ресурс] - Режим доступу: www.zakonoproekt.org.ua/viewhtm.aspx?hn=Pojasnjuvaljna_zapyska_14_03_20132

8. Передрій O.I. Екологічні аспекти використання безфосфатних пральних засобів [текст] / O.I. Передрій //Товарознавчий вісник : збірник наукових праць ЛНТУ. 2012. - Випуск 5. - С.138-146.

9. Передрий О.И. Исследование потребительских свойств бесфосфатных моющих средств [текст] / О.И. Передрий // Потребительская кооперация. - 2014. - №2 (45). - C. 67-71.

10. Кабінет Міністрів України. Постанова від 13 січня 2016 р. № 95 «Про затвердження модулів оцінки відповідності, які використовуються для розроблення процедур оцінки відповідності, та правил використання модулів оцінки відповідності». [Електронний ресурс]. - Режим доступу : http://zakon.rada.gov.ua/go/95-2016-\%D0\%BF

11. Про затвердження Класифікатора додаткової інформації, необхідної для ідентифікації товарів, що вноситься до електронного інвойсу, який додається до митної декларації, заповненої на бланку САД - [Електронний ресурс]. - Режим доступу : http://zakon2.rada.gov.ua/laws/show/z1691-12.

Цель. Определение признаков идентификаџии синтетических моющих средств в соответствии с требованиями технических регламентов при осуществлении таможенных процедур. Важным является установление основных признаков идентификачии синтетических моющих средств в таможенных иелях.

Методика. При проведении исследований использовали методы на основе системного анализу и органолептические методь визуального контроля. Для подведения результатов роботь использовали методы анализа и синтеза, абстрагирования $u$ группирования.

Результаты. Проанализированы представленные данные крупнейших в мире странэкспортеров и стран-импортеров синтетических моющих средств в 2017 году. Очерчень определения основных требований по качеству и экологической безопасности синтетических моющих средств в свете гармонизаџии требований технических регламентов. Определены признаки товароведной и таможенной идентификации. Поскольку идентификация с таможенной целью является составляющей необходимых таможенных процедур, а именно таможенного оформления при осуществлении внешнеэкономических операџий.

Научная новизна. Проведен анализ признаков таможенной идентификации, как критерия таможенной классификации во время декларирования синтетических моюших средств, являюшихся обьектом внешнеэкономических операщий. Определен оптимальный 
перечень признаков классификаџии синтетических моющих средств, позволяющий достаточно идентифицировать с таможенной целью при осуществлении таможенных проиедур.

Практическая значимость. Установленные критерии идентификации синтетических моюших средств позволяют четко классифицировать объект таможенного контроля с иелью использования механизмов таможенного тарифного $и$ нетарифного регулирования.

Ключевые слова: идентификачия, синтетические моющие средства, классификация, ассортимент, таможенный контроль, таможенное оформление, технический регламент.

Purpose. Definition of the identification signs of synthetic detergents in accordance with the requirements of technical regulations during the implementation of customs procedures. The establishment of the main features of the identification of synthetic detergents for customs purposes is important.

Methodology. The methods based on system analysis and organoleptic methods of visual control were used in the research. The methods of analysis and synthesis of information, abstraction, and grouping were used to summarize the paper.

Findings. The submitted data for the world largest exporting and importing countries of synthetic detergents in 2017 is analyzed. The definitions of the basic requirements concerning the quality and environmental safety of synthetic detergents in the light of the harmonization of the requirements of technical regulations are outlined. The signs of commodity and customs identification are identified. Identification for customs purposes is an integral part of the required customs procedures, namely customs clearance when conducting foreign trade operations.

Originality. The analysis of customs identification signs as a criterion for customs classification during the declaration of synthetic detergents, which is the object of foreign economic operations, has been carried out. An optimal list of classification features of synthetic detergents allowing to identify sufficiently for customs purposes during the implementation of customs procedures has been established.

The practical value. The identified criteria for the identification of synthetic detergents allow to clearly classify the object of customs control with the aim of applying customs tariff and nontariff regulation mechanisms.

Keywords: identification, Synthetic detergents, classification, assortment, customs control, customs processing, technical regulations.

Рекомендовано до публікації докт.техн.наук. професором Луизького НТУ Байдаковою Л.І. Дата надходження в редакиію 03.08.2018 р. 